\title{
Regulation of Brittle Diabetics by a Pre-Planned Insulin Infusion Programme
}

\author{
T. Deckert and B. Lørup \\ Steno Memorial Hospital, Gentofte, Denmark
}

Summary. Eleven brittle diabetics, mean duration 11.5 years, all treated with highly purified porcine $\mathrm{NPH}$ insulin twice daily, were placed on highly purified porcine regular insulin 4 times daily for 2 days. Thereafter pre-planned intravenous insulin infusion was started. Insulin in an amount corresponding to the daily insulin requirement was infused by a mobile electric infusion pump at precalculated rates between 30 and $7 \mathrm{ml} /$ hour during 2 days. The patients were ambulatory. Capillary blood glucose was taken every $30 \mathrm{~min}$ after meals and every two hours during the night. After an equilibration period of 7 hours, blood glucose fluctuations were in the physiological range in nearly all patients during the infusion period. [Only $1.3 \%$ of the blood samples showed glucose levels lower than $2.5 \mathrm{mmol} / 1$ and $2.9 \%$ levels exceeding $10.0 \mathrm{mmol} / 1$ during the infusion days]. Mean blood glucose $(\mathrm{MBG})$ was $6.0 \pm 0.9 \mathrm{mmol} / 1$ (mean $\pm \mathrm{s}$. d.), the standard deviation of MBG was $1.8 \pm 0.5 \mathrm{mmol} / 1$, the mean amplitude of blood glucose excursions (MAGE) $4.7 \pm 1.4 \mathrm{mmol} / 1$, and glucosuria $3.1 \pm 3.9$ $\mathrm{g}$ /day. All these data of glucose homeostasis were significantly lower during the infusion days. The incidence of hypoglycaemic attacks was low (0.32/patient/day) and not significantly higher than during NPH treatment. It is concluded that near normal blood glucose fluctuations can be achieved in brittle diabetics by preplanned insulin infusion without blood glucose monitoring.

Key words: Insulin infusion, artificial pancreas, brittle diabetics.

In spite of insulin treatment, diet, and medical control, life expectancy and "quality of life" are reduced in juvenile diabetics (diabetics who have to be treated with insulin before the age of 30) [7]. The cause of the poor prognosis is the development of nephropathy and of cardiovascular disease which seems to be dependent on the quality of metabolic control during the preceding years $[7,8,12,17,24]$. To reduce the risk of severe late diabetic manifestations, diabetologists all over the world are trying to achieve good metabolic control in juvenile diabetics.

This often seems to be impossible and such patients are called brittle diabetics. In these cases the basic daily insulin requirement can be met preventing the development of ketoacidosis, severe hypoglycaemia, weight gain or loss and other diabetic symptoms, but there remain wide and unphysiological daily fluctuations in blood glucose and many other metabolites and hormones $[1,4,11,21]$.

These fluctuations seem to be due to inadequate variations of the plasma concentration of pancreatic islet hormones (insulin, glucagon, and somatostatin), since pancreatic transplantation is able to prevent them entirely [14]. Nothing is known about the role of pancreatic somatostatin in the metabolic regulation of diabetes, whereas pancreatic glucagon seems to be of importance [4.22]. The unphysiological variation of plasma pancreatic glucagon in diabetic animals appears to be induced by lack of insulin, and this may be the case in human diabetics [15]. Consequently, it seems to be of the utmost importance to keep plasma insulin concentration within the physiological range in order to prevent fluctuations of metabolites and hormones in brittle diabetics.

In non-diabetics the plasma insulin concentration fluctuates as seen in Figure 1. These fluctuations of plasma insulin are of importance for blood glucose homeostasis, since intravenous infusion of insulin at a constant rate to brittle diabetics lacking endogenous insulin [9] results in marked elevations of blood glucose after meals (Fig. 2). 

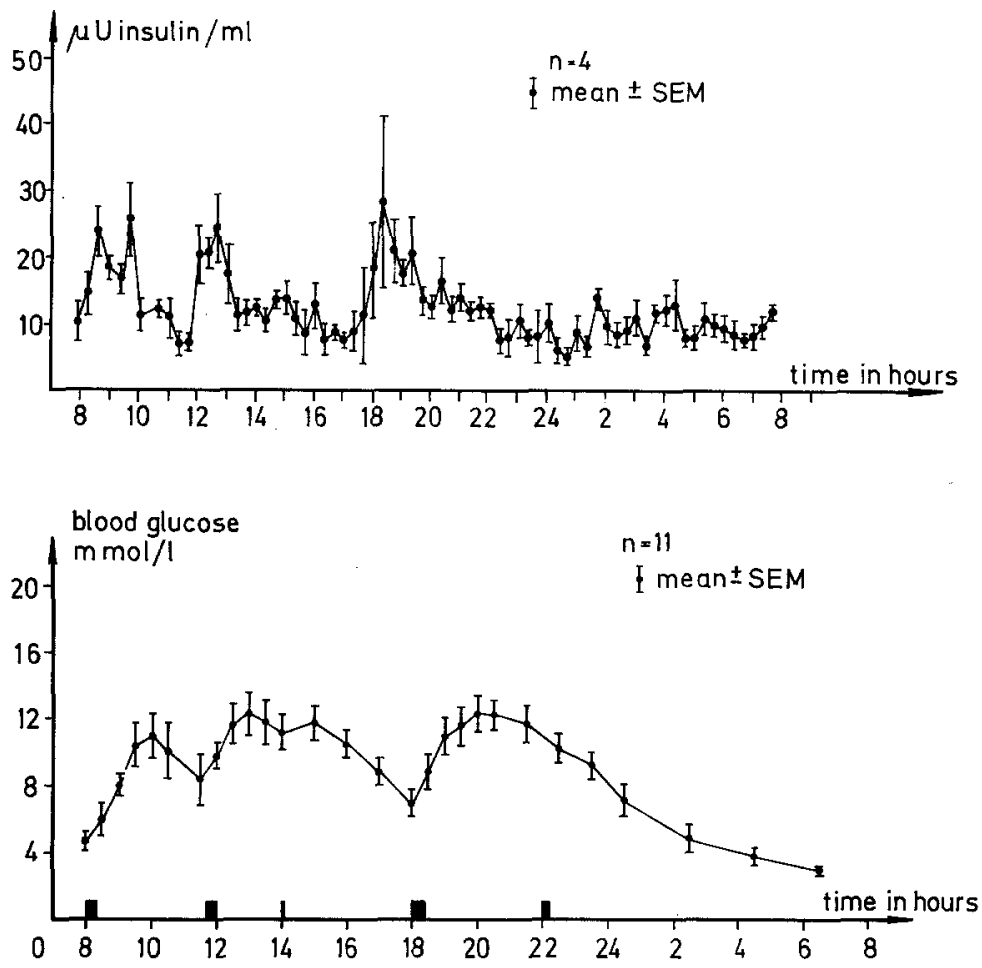

Fig. 1. Plasma insulin variation during one day in nondiabetics. Mean \pm SEM of 4 volunteers. (We are grateful to Dr. Mølholm Hansen for sampling the sera.)
Fig. 2. Capillary blood glucose during intravenous insulin infusion at a constant rate $(0.26-$ 0.53 , mean $0.39 \mathrm{mU} / \mathrm{kg} / \mathrm{min}$ ) in 4 insulintreated normal-weight diabetics. 3 patients were of the juvenile brittle type, one patient of the more stable type. Mean $\doteq$ SEM of 11 infusion days
To keep the blood glucose concentration within the physiological range in brittle diabetics we therefore developed a programme of infusing soluble insulin intravenously at rates which would imitate physiological plasma insulin variations in non-diabetics in everyday life. This paper describes the method of insulin infusion and the results in 11 consecutive brittle diabetics given ambulatory insulin infusion for 2 days after unsuccessful regulation on NPH insulin twice daily as well as soluble insulin 4 times daily.

\section{Material and Methods}

\section{Material}

The group of brittle diabetics consisted of 11 diabetics -7 males and 4 females - referred to the Steno Memorial Hospital, one of the diabetic centres in Denmark. The patients had been referred to the hospital by practitioners or departments of internal medicine because of difficulties in achieving acceptable metabolic control. The patients' data are given in Table 1. In 8 the diagnosis of diabetes had been established before the age of 20 , in the other 3 after the age of 35 (mean 16.6 years of age). One patient was obese $(+16 \%$ of ideal body weight according to the tables of Natvig [16]. The other patients were normal - or under- weight. The duration of diabetes and insulin treatment varied between 4 and 21 years (mean 11.5 years), which means that any preservation of endogenous insulin secreting capacity was unlikely [9]. 7 of the patients had already developed late diabetic manifestations (retinopathy and/or neuropathy), but none had Albustix-positive proteinuria. All the patients had been treated with highly purified porcine NPH insulin (insulin Leo Retard $\mathrm{RI}^{\circledR}$ ) twice daily for several years; 8 patients mixed NPH with shortacting insulin in the morning. In all cases the daily insulin requirement (mean 48 units) exceeded 35 units, the mean of the daily insulin requirement in adult Danish insulin-requiring diabetics [6]. During the first 5 to 10 days in hospital (mean 6.7 days) the patients were ambulatory with ordinary physical activities (long walks, bicycle rides) and on a regular diet of 1500-2300 cal. (mean 1929) including about $200 \mathrm{~g}$ carbohydrates a day (Table 1). The usual insulin was given by the nurses twice daily, 30 min before breakfast and supper in varying amounts based on capillary blood glucose determination 5 times daily. All patients were without symptoms or complicating diseases and without ketonuria after one day of treatment.

Since after several days of hospital treatment the patients were still difficult to regulate, the usual insulin treatment was stopped and replaced with highly 
Table 1. Individual data of 11 brittle diabetics. For definition of $a_{2}, b, c_{1}$, and $c_{2}$, see Fig. 3

\begin{tabular}{|c|c|c|c|c|c|c|c|c|c|c|c|c|c|c|}
\hline \multirow[t]{2}{*}{ No. } & \multirow[t]{2}{*}{ Sex } & \multirow[t]{2}{*}{$\begin{array}{l}\text { Age } \\
\text { (years) }\end{array}$} & \multirow{2}{*}{$\begin{array}{l}\% \text { of } \\
\text { ideal } \\
\text { body- } \\
\text { weight }\end{array}$} & \multirow{2}{*}{$\begin{array}{l}\text { Durati- } \\
\text { on of } \\
\text { diab. } \\
\text { (years) }\end{array}$} & \multirow{2}{*}{$\begin{array}{l}\text { Reti- } \\
\text { nopa- } \\
\text { thy }\end{array}$} & \multirow{2}{*}{$\begin{array}{l}\text { Neuro- } \\
\text { pathy. }\end{array}$} & \multirow[t]{2}{*}{$\begin{array}{l}\text {-Diet } \\
\text { Calories }\end{array}$} & \multirow{2}{*}{$\begin{array}{l}\text { Carbo- } \\
\text { hydra- } \\
\text { tes (g) }\end{array}$} & \multicolumn{4}{|c|}{$\begin{array}{l}\text { Daily insulin dose } \\
\text { given (units) }\end{array}$} & \multirow{2}{*}{$\begin{array}{l}\text { Ins. } / \mathrm{kg} \\
\text { body weight } \\
\text { (units) }\end{array}$} & \multirow{2}{*}{$\begin{array}{l}\text { Fasting blood } \\
\text { glucose on } 1 . \mathrm{st} \\
\text { infusion day } \\
(\mathrm{mmol} / \mathrm{l})\end{array}$} \\
\hline & & & & & & & & & $a_{2}$ & b & $\mathrm{c}_{1}$ & $c_{2}$ & & \\
\hline 1 & $\mathrm{~m}$ & 24 & 98 & 4 & 0 & 0 & 2016 & 222 & 48 & 50 & 48 & 48 & 0.69 & 17.1 \\
\hline 2 & $\mathrm{~m}$ & 14 & 96 & 8 & 0 & 0 & 2243 & 255 & 48 & 53 & 48 & 48 & 0.84 & 16.1 \\
\hline 3 & $\mathrm{~m}$ & 21 & 92 & 8 & 0 & 0 & 2119 & 233 & 50 & 52 & 52 & 42 & 0.81 & 18.0 \\
\hline 4 & $\mathrm{~m}$ & 56 & 104 & 12 & 0 & + & 2158 & 249 & 32 & 43 & 36 & 36 & 0.50 & 14.0 \\
\hline 5 & $\mathrm{~m}$ & 18 & 107 & 14 & + & 0 & 1986 & 185 & 52 & 50 & 50 & 48 & 0.77 & 14.8 \\
\hline 6 & f & 21 & 84 & 13 & 0 & + & 1510 & 148 & 46 & 48 & 46 & 44 & 0.89 & 16.0 \\
\hline 7 & f & 19 & 88 & 13 & + & 0 & 1655 & 169 & 52 & 52 & 54 & 52 & 0.94 & 18.9 \\
\hline 8 & $\mathrm{f}$ & 25 & 95 & 21 & + & 0 & 1588 & 145 & 42 & 39 & 36 & 36 & 0.65 & 17.8 \\
\hline 9 & $\mathrm{~m}$ & 44 & 93 & 4 & 0 & 0 & 2326 & 259 & 42 & 46 & 50 & 50 & 0.65 & 16.4 \\
\hline 10 & $\mathrm{~m}$ & 52 & 116 & 16 & + & + & 1724 & 175 & 54 & 49 & 56 & 54 & 0.67 & 12.7 \\
\hline 11 & f & 15 & 90 & 14 & 0 & + & 1898 & 180 & 52 & 53 & 58 & 54 & 1.08 & 14.2 \\
\hline mean & $4 / 7$ & 28.1 & 96.6 & 11.5 & $4 / 11$ & $4 / 11$ & 1929 & 202 & 47.1 & 48.6 & 48.5 & 46.5 & 0.772 & 16.0 \\
\hline \pm s. d. & & 15.1 & 9.2 & 5.1 & & & 277 & 43 & 6.4 & 4.4 & 7,2 & 6.4 & 0.16 & 1.9 \\
\hline
\end{tabular}

purified porcine regular insulin (insulin Leo Neutral $\left.\mathrm{RI}^{\circledR}\right) 4$ times daily subcutaneously. The day before the first day on regular insulin, capillary blood glucose was determined, in all patients except the first one, every $30 \mathrm{~min}$ after meals, and every two hours during the night (Fig. 4). Regular insulin was given in order to achieve a more physiological plasma insulin concentration during the 3 chief meals and in order to eliminate all NPH insulin from the subcutaneous tissue before starting intravenous insulin infusion. Of the total daily insulin requirement, about $30 \%$ was given at 7 a. m., about $25 \%$ at 12 noon, about $30 \%$ at 6 p. m. and $15 \%$ at midnight. Each insulin dose was determined from blood glucose measurements. Capillary blood glucose on these days was determined at least 5 times daily. After 2 days on regular insulin, intravenous insulin infusion was started. The whole procedure is illustrated in Figure 3.

\section{Methods}

Two days of continous intravenous insulin infusion followed upon 7-12 days (mean 8.7 days) of carefully supervised subcutaneous insulin therapy in hospital. The infusion was started at $8.00 \mathrm{a} . \mathrm{m}$. and given by an electric precision pump (Infusomat ${ }^{\circledR}$ ) placed on a mobile stand easily transported by the patient, who followed the usual hospital routine (bedroom, sittingroom, toilet etc.). The meals are shown in Figures 4 and 5. Physical exercise (E) was done on a bicycle 3 times daily for $30 \mathrm{~min}$, from $10.30-11.00$ a.m., 3.00-3.30 p. m., 6.30-7.00 p. m.

In all patients the infusion rate was varied according to the same programme. This programme was

developed on the basis of infusion experiments carried out in other diabetics and indicated that physiologic postprandial plasma insulin variations could be achieved by increasing the basal insulin infusion rate (resulting in a plasma insulin concentration of e. g. 15 $\mu \mathrm{U} / \mathrm{ml}$ ) 4-5 times, followed by a gradual decrease of the insulin infusion rate. According to these experiments, the following infusion programme was used in each of the 11 patients:

time

$$
\begin{array}{r}
8.00-9.30 \\
9.30-12.00 \\
12.00-13.00 \\
13.30-15.00 \\
15.00-16.00 \\
16.00-18.00 \\
18.00-20.00 \\
20.00-21.30 \\
21.30-00.30 \\
00.30-08.00
\end{array}
$$

$$
\begin{aligned}
& \text { infusion rate } \\
& 30 \mathrm{ml} / \text { hour } \\
& 15 \mathrm{ml} / \text { hour } \\
& 30 \mathrm{ml} / \text { hour } \\
& 20 \mathrm{ml} / \text { hour } \\
& 15 \mathrm{ml} / \text { hour } \\
& 10 \mathrm{ml} / \text { hour } \\
& 30 \mathrm{ml} / \text { hour } \\
& 15 \mathrm{ml} / \text { hour } \\
& 10 \mathrm{ml} / \text { hour } \\
& 7 \mathrm{ml} / \text { hour }
\end{aligned}
$$

\section{(see Fig. 5)}

The infusion rate was easily changed by the patient himself by turning a button on the pump. The infusion programme was identical on both infusion days and the infusion volume was $360.5 \mathrm{ml} /$ day on all experimental days.

Thus the only parameter which varied between the individual patients was the insulin concentration of the insulin solution. The individual insulin solution was prepared after estimating the total daily insulin requirement on the basis of the preceding days, obser- 


\begin{tabular}{|c|c|c|c|c|}
\hline$a$ & & $b$ & \multicolumn{2}{|c|}{ c } \\
\hline$a_{1}$ & $a_{2}$ & & $c_{1}$ & $c_{2}$ \\
\hline 5 - 10 days & & 2 days & \multicolumn{2}{|c|}{2 days } \\
\hline $\begin{array}{l}\text { NPH-INSULIN } \\
\text { subcut. } \\
2 \times \text { daily }\end{array}$ & & $\begin{array}{l}\text { Regular } \\
\text { INSULIN } \\
\text { subcut. } \\
4 \text { xdaily }\end{array}$ & \multicolumn{2}{|c|}{$\begin{array}{l}\text { Regular } \\
\text { INSULIN } \\
\text { intrav. } \\
\text { cont. }\end{array}$} \\
\hline
\end{tabular}
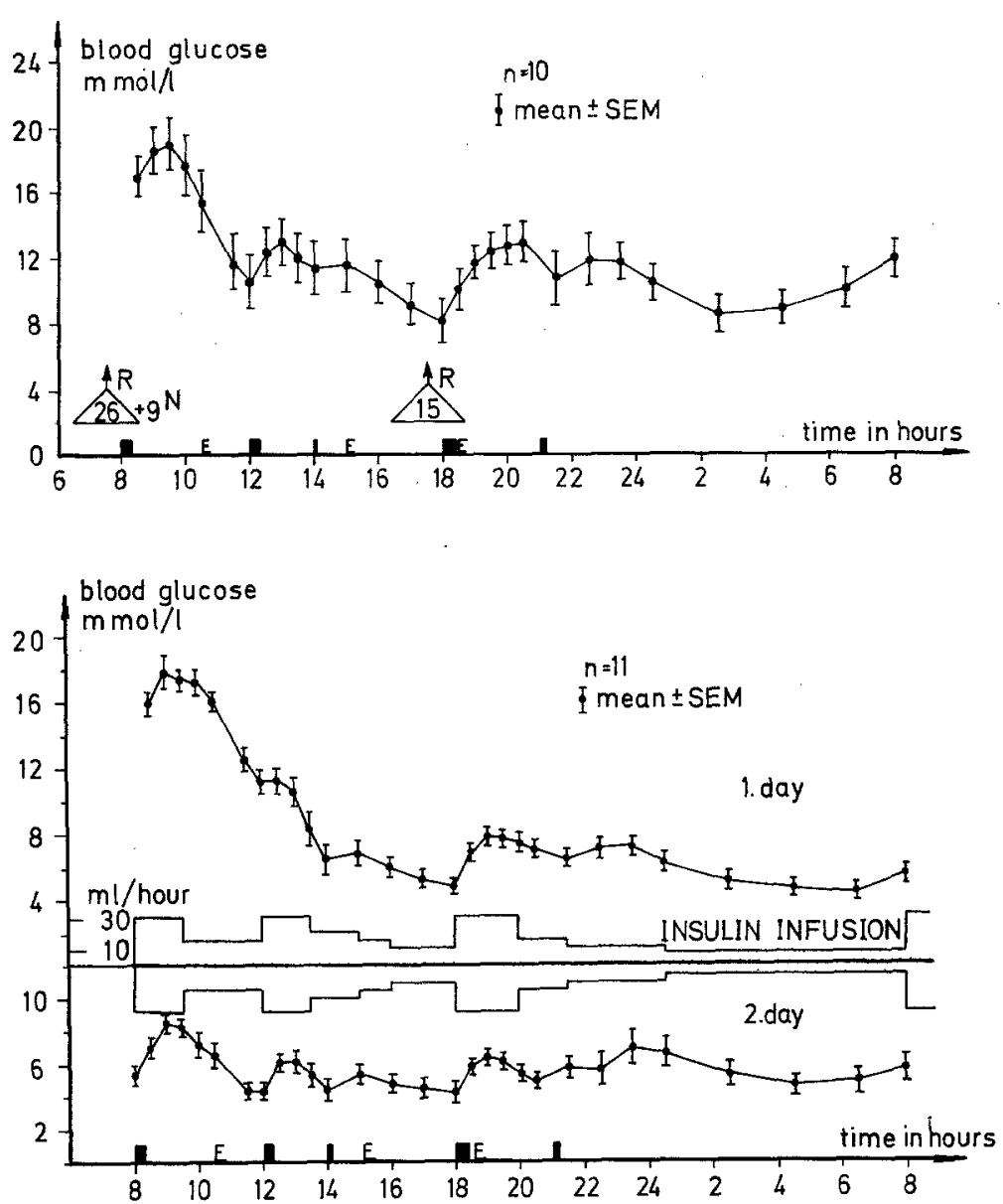

Fig. 3. Procedure in regulation of brittle diabetics. a: period of NPH-insulin treatment; $b$ : period of regular insulin treatment; $c$ : period of insulin infusion treatment. During $a_{1}$ blood glucose was determined at least 5 times daily. During $\mathrm{a}_{2}$ blood glucose was determined at least 28 times daily. During b blood glucose was determined at least 5 times daily. During $\mathrm{c}$ blood glucose was determined at least 28 times daily
Fig. 4. Capillary blood glucose during the last day on NPH insulin treatment. Mean \pm SEM of 10 brittle diabetic patients. The black squares indicate meals, $E=$ physical exercise. The mean insulin dose was given at the arrows. $1 \hat{S}^{\mathrm{R}}=15$ units of highly purified porcine NPH insulin (Insulin Leo Retard $R I^{\circledR}$ ), $9^{N}=9$ units of highly purified porcine regular insulin (Insulin Leo Neutral RI ${ }^{\circledR}$ )
Fig. 5. Capillary blood glucose during the 2 infusion days. Mean \pm SEM of 11 brittle diabetics. The black squares indicate meals, $\mathrm{E}=$ physical exercise. The insulin infusion rate is given in $\mathrm{ml}$ solution/hours vations at the outpatient clinic and earlier hospitalizations. Highly purified porcine regular insulin (insulin Leo Neutral $\mathrm{RI}^{\circledR}$ ) at an amount corresponding to 1.4 times the estimated daily insulin dose was dissolved in $500 \mathrm{ml}$ isotonic phosphate-sodium chloride solution, $\mathrm{pH}$ 7.4. $2^{1 / 2} \mathrm{~g}$ of human albumin (Statens Seruminstitut) was added in order to prevent adsorption of insulin to bottles and tubes [10]. Since every patient only received $360.5 \mathrm{ml}$ of the solution a day, of the estimated daily insulin requirement was thus secured.
Every day a freshly prepared insulin solution was used in order to avoid bacterial growth. Only small adjustments of the total insulin amount in the solution were made before starting the second day infusion (see Table 1).

No fall in insulin concentration was found in the infusion bottles during 24 hours at room temperature.

Capillary blood was taken from the ear lobe 28 times a day for whole blood glucose determination by the glucose oxidase method (Figures 4 and 5). Glu- 
Table 2. Mean blood glucose (MBG), standard deviation (s. d.) of MBG, mean amplitude of blood glucose excursions (MAGE), glucose excretion in urine/day, and incidence of hypoglycaemic attacks/day in 11 brittle diabetics. Furthermore, maximum and minimum blood glucose values during the NPH insulin day (a) and the insulin infusion period (c) are given. For definition of $\mathrm{a}_{2}, \mathrm{~b}, \mathrm{c}_{1}$, and $\mathrm{c}_{2}$, see Fig. 3. MBG: $a_{2}$ vs. $b: p<0.01 ; b$ vs. $c_{1}: p<0.001 ; b$ vs. $c_{2}: p<0.001$. s. d. of MBG: $a_{2}$ vs. $b:$ n. s.; b vs. $c_{1}: p<0.001 ; b$ vs. $c_{2}: p<0.001$. MAGE: $a_{2}$ vs. b:n. s.; b vs. c:p $<0.01$. Glucosuria: $a_{2}$ vs. $c: p<0.001$

\begin{tabular}{|c|c|c|c|c|c|c|c|c|c|c|c|c|c|c|c|c|c|c|c|}
\hline \multirow[t]{2}{*}{ No. } & \multicolumn{4}{|c|}{$\begin{array}{l}\text { MBG } \\
(\mathrm{mmol} / \mathrm{l})\end{array}$} & \multicolumn{4}{|c|}{$\begin{array}{l}\text { s. d. of MBG } \\
(\mathrm{mmol} / \mathrm{l})\end{array}$} & \multicolumn{3}{|c|}{$\begin{array}{l}\text { Mage } \\
(\mathrm{mmol} / \mathrm{l})\end{array}$} & \multicolumn{3}{|c|}{$\begin{array}{l}\text { Glucosuria } \\
\text { (g/day) }\end{array}$} & \multicolumn{3}{|c|}{$\begin{array}{l}\text { Hypoglycae- } \\
\text { mic attacks }\end{array}$} & \multirow{2}{*}{\multicolumn{2}{|c|}{$\begin{array}{l}\text { Maximum vs. } \\
\text { minimum blood glu- } \\
\text { cose during period } \\
a_{2}(\mathrm{mmol} / \mathrm{l}) \mathrm{c}\end{array}$}} \\
\hline & $a_{2}$ & b & $\mathrm{c}_{1}$ & $c_{2}$ & $a_{2}$ & $\mathrm{~b}$ & $c_{1}$ & $c_{2}$ & $a_{2}$ & b & c & $a_{2}$ & b & c & $a_{2}$ & b & $c$ & & \\
\hline 1 & 10.8 & 8.7 & 7.5 & 5.2 & 6.2 & 4.4 & 1.8 & 1.5 & 6.1 & 8.8 & 3.7 & 64 & 21 & 0 & 1 & 1.5 & 0.5 & $\begin{array}{r}20.0 \\
3.6 \\
20.2\end{array}$ & $\begin{array}{r}11.6 \\
2.6 \\
8.8\end{array}$ \\
\hline 2 & 11.3 & 11.0 & 5.5 & 5.9 & 4.8 & 5.0 & 1.2 & 1.4 & 15.4 & 12.1 & 2.5 & 36 & 41 & 0 & 1 & 0.5 & 0.5 & $\begin{array}{r}4.8 \\
27.8\end{array}$ & $\begin{array}{l}3.7 \\
9.9\end{array}$ \\
\hline 3 & 17.3 & 12.8 & 6.6 & 6.9 & 5.6 & 5.2 & 1.3 & 1,4 & 20.8 & 12.8 & 3.9 & 80 & 43 & 12 & 0 & 0.5 & 0.5 & $\begin{array}{r}7.0 \\
22.6\end{array}$ & $\begin{array}{r}4.1 \\
11.6\end{array}$ \\
\hline 4 & 17.1 & 10.3 & 6.4 & 7.4 & 2.4 & 4.5 & 2.8 & 2.3 & 6.9 & 8.9 & 6.8 & 88 & 19 & 5 & 0 & 1.5 & 0 & $\begin{array}{l}13.5 \\
15.1\end{array}$ & $\begin{array}{r}1.8 \\
10.7\end{array}$ \\
\hline 5 & 10.7 & 6.3 & 6.1 & 6.3 & 3.3 & 1.8 & 1.2 & 2.2 & 6.8 & 3.9 & 7.0 & 28 & 2 & 5 & 0 & 1 & 0.5 & $\begin{array}{r}5.1 \\
15.8\end{array}$ & $\begin{array}{l}2.9 \\
9.5\end{array}$ \\
\hline 6 & 9.0 & 9.8 & 6.2 & 4.3 & 3.4 & 3.7 & 2.1 & 1.3 & 7.5 & 8.2 & 4.0 & 8 & 18 & 2 & 0 & 0.5 & 0.5 & $\begin{array}{r}3.8 \\
20.3\end{array}$ & $\begin{array}{l}2.4 \\
9.9\end{array}$ \\
\hline 7 & 12.3 & 11.2 & 5.8 & 5.5 & 4.2 & 2.6 & 2.0 & 2.1 & 11.4 & 5.7 & 5.1 & 27 & 17 & 0 & 1 & 0 & 0 & $\begin{array}{r}4.5 \\
21.4\end{array}$ & $\begin{array}{r}2.7^{7} \\
11.9\end{array}$ \\
\hline 8 & 12.8 & 6.6 & 6.4 & 7.0 & 4.3 & 4.1 & 1.3 & 3.1 & 14.1 & 6.9 & 5.3 & 57 & 5 & 7 & 0 & 1 & 0 & $\begin{array}{r}7.1 \\
22.0\end{array}$ & $\begin{array}{r}3.0 \\
12.0\end{array}$ \\
\hline 9 & 13.7 & 11.6 & 7.0 & 5.9 & 4.3 & 4.7 & 2.5 & 1.8 & 6.2 & 10.1 & 5.7 & 48 & 50 & 3 & 0 & 0 & 0 & $\begin{array}{r}7.0 \\
12.6\end{array}$ & $\begin{array}{l}3.1 \\
8.5\end{array}$ \\
\hline 10 & 7.3 & 7.7 & 5.0 & 5.0 & 2.0 & 2.5 & 1.6 & 1.3 & 6.1 & 9.1 & 3.5 & 6 & 7 & 0 & 0 & 0 & 0.5 & $\begin{array}{r}3.4 \\
20.0\end{array}$ & $\begin{array}{r}2.7 \\
10.7\end{array}$ \\
\hline 11 & 11.6 & 9.7 & 4.8 & 5.0 & 4.3 & 3.3 & 1.9 & 2.3 & 11.0 & 9.1 & 5.0 & 8 & 9 & 0 & 0 & 0 & 0.5 & 5.2 & 1.6 \\
\hline $\begin{array}{l}\text { mean } \\
\pm \mathrm{s} . \mathrm{d} \text {. }\end{array}$ & $\begin{array}{r}12.2 \\
3.0\end{array}$ & $\begin{array}{l}9.6 \\
2.1\end{array}$ & 6.1 & $\begin{array}{l}5.9 \\
10\end{array}$ & 4.1 & $\begin{array}{l}3.8 \\
11\end{array}$ & $\begin{array}{l}1.8 \\
0.5\end{array}$ & $\begin{array}{l}1.9 \\
0.6\end{array}$ & $\begin{array}{r}10.2 \\
4.9\end{array}$ & $\begin{array}{l}8.7 \\
2.6\end{array}$ & $\begin{array}{l}4.7 \\
1.4\end{array}$ & $\begin{array}{l}40.9 \\
28.9\end{array}$ & $\begin{array}{l}21.0 \\
16.5\end{array}$ & $\begin{array}{l}3.1 \\
3.9\end{array}$ & 3 & 6.5 & 3.5 & $\frac{19.8 \pm 4.1}{59+29}$ & $\frac{10.5 \pm 1.2}{28+07}$ \\
\hline
\end{tabular}

cose in 24-hour urine samples was also determined by the glucose oxidase method. On the basis of all capillary blood glucose determinations on each day, the mean blood glucose (MBG) \pm standard deviation (s. d.) was calculated for each patient. Because of highly elevated fasting blood glucose on the first infusion day (Tab. 1 and Fig. 5), an equilibrium period of 7 hours was allowed before calculation was started on that day. As a measure of blood glucose fluctuations in the individual patients, apart from the standard deviation of MBG, the mean amplitude of glucose excursions (MAGE) was calculated according to Molnar [18]. Again an equilibrium period of 7 hours was allowed before calculation started on the first infusion day. Hypoglycaemic reactions were recorded when the patients had appropriate symptoms and blood glucose levels lower than $5.0 \mathrm{mmol} / \mathrm{l}$. Immunologically reactive insulin in the infusion bottles and in plasma from non-diabetics was measured after adequate dilution by the solid phase technique of Wide [23].

\section{Results}

All patients felt well. In 3 cases the infusion had to be interrupted - after 34,35 , and 38.5 hours-because of paravenous infusion, phlebitis, and break-down of the pump respectively. In all the other cases the cubital vein infusion was continued for 48 hours.

Figure 4 demonstrates the high blood glucose levels, the huge SEM (1.2-2.2 $\mathrm{mmol} / \mathrm{l})$, and the wide fluctuations (8-19 mmol/1) of blood glucose during the last day on NPH insulin. This is in contrast to Figure 5, which demonstrated the mean blood glucose variation during the 2 days on insulin infusion during which - after the equilibrium period - the level is in the physiological range, the fluctuations much less marked (4.2-8.4 mmol/1), and the SEM halved. Only $1.3 \%$ of the blood glucose determinations were less than $2.5 \mathrm{mmol} / \mathrm{l}$ on the infusion days after the equilibrium period of 7 hours, and $2.9 \%$ of the samples exceeded $10.0 \mathrm{mmol} / \mathrm{l}$. The maximum and minimum 
glucose levels are given in Table 2. The incidence of hypoglycaemic reactions during the infusion days was about the same as on the NPH day, but lower than on the days on which regular insulin was given subcutaneouslv 4 times daily. The daily insulin dose was not significantly different on the NPH day, days with regular insulin, and infusion days (see Table 1). Table 2 also demonstrates $\mathrm{MBG} \pm$ standard deviation, MAGE, and glucosuria. It is seen that the mean MBG, standard deviation, MAGE, and glucosuria were greatly, and significantly, reduced on the infusion days (Table 2).

\section{Discussion}

Normal blood glucose homeostasis in brittle diabetics may be established by pancreas- [14] or islet transplantation [13] or by using an artificial pancreas [2]. Since the technical, immunological and ethical problems concerning pancreas- or islet transplantation may be difficult or impossible to solve [3], it cannot be excluded that diabetic treatment by an artificial pancreas may be a possibility in the future. So far, however, an artificial pancreas is too complicated and too large for ambulatory clinical use, since a glucose-sensor has to be implanted, blood has to be withdrawn, and insulin has to be infused continously, periodically together with considerable amounts of glucose. If automatic glucose analysis can be avoided, the technical problems would be greatly reduced. Slama et al. [20] have tested a portable insulin infusion pump in 7 diabetics. Insulin was given intravenously at two different rates. However, blood glucose control during the infusion days was not superior to that on subcutaneous treatment with short-acting insulin 3 times daily. This was presumably because these patients were stable insulin-dependent diabetics, already very well regulated on subcutaneous insulin therapy with short acting insulin 3 times daily.

The infusion programme described in this paper gave a significantly better blood glucose control than treatment with NPH-insulin or short-acting insulin 4 times daily, although the infusion programme was not altered from patient to patient. This amelioration of blood glucose homeostasis was presumably achieved because the plasma insulin concentration varied in a more physiological manner. In normals and diabetics without insulin antibodies the plasma concentration of insulin will rapidly change after the insulin infusion rate has been changed, because insulin has a rather high turnover rate [19].

By giving insulin intravenously, unpredictable $a b-$ sorption from the subcutaneous insulin depots can be avoided [5] and so can dermatological and probably also immunological side effects [6].

The only important prerequisite for successful insulin infusion treatment - besides a reasonable programme - is a fairly good estimate of the daily insulin requirement. It was interesting that not infrequently the blood glucose concentration was lower than on the NPH days without causing hypoglycaemic sensations and/or counter-regulation. It was also interesting to see that blood glucose rises significantly in the early morning during constant insulin infusion (Fig. 5), presumably because the plasma cortisol concentration rises, resulting in increasing insulin need. Further work, using a more convenient pump, is in progress.

\section{References}

1. Alberti, K. G. M. M.: Blood metabolites in the diagnosis and treatment of diabetes mellitus. Postgrad. med. J, 49, 955-963 (1973)

2. Albisser, A. M., Leibel, B. S., Ewart, T. G., Davidovac, Z., Botz, C. K., Zingg, W., Schipper, H., Gander, R.: Clinical control of diabetes by artificial pancreas. Diabetes 23, 397-404 (1974)

3. Andersen, O. O., Deckert, T., Nerup, J.: Immunological aspects of diabetes mellitus. Symposium held in Copenhagen 28-30 August 1975. Acta endocr. (Kbh.) Suppl. (in press 1976)

4. Assan, R., Attali, J. R., Ballerio, G., Girard, J. R., Hautecouverture, M., Kervran, A., Plouin, P. F., Slama, G., Soufflet, E., Tchobroutsky, G., Tiengo, A.: Some aspects of the physiology of glucagon. In: Diabetes (eds. W. J. Malaisse, J. Pirart), pp. 144-179. Excerpta Medica 312, Amsterdam 1974

5. Binder C.: Absorption of injected insulin. In: Thesis. p. 50. Copenhagen: Munksgaard 1969

6. Deckert, T., Andersen, O. O., Poulsen, J. E.: The clinical significance of highly purified pig-insulin preparations. Diabetologia 10, 730-708 (1974)

7. Deckert, T., Poulsen, J. E., I arsen, M.: Prognosis in juvenile diabetes mellitus. Diabetologia 11, 337 (1975)

8. Engermann, R. L., Bloodworth, J. M. B.: Role of diabetes control in microvascular disease. VIII Congress of the International Diabetes Federation. Excerpta med. (Amst) 280, 188 (1973)

9. Enk, B., Deckert, T.: Insulin secretion in insulin-requiring diabetics before and during insulin treatment. Diabetologia 11, 340 (1975)

10. Enk B., Eff, C.: Insulinadsorption til infusionsmaterialer. Ugeskr. Laag. 8, 479-481 (1976)

11. Hanssen, K. F.: Immunoreactive growth hormone in plasma and urine in juvenile diabetics before and during initial insulin treatment. Acta endocr. (Kbh.) 75, 50-63 (1974)

12. Lauvaux, J. P., Pirart, J., Eisendrath, C.: The course of diabetic retinopathy: A statistical study on its development, progression and regression in 4400 diabetics. Diabetologia 11, 358 (1975)

13. Lazarow, A., Wells, L. J., Carpenter, A. M., Hegre, O. D., Leonard, R. J., McEvoy, R. C.: Islets differentiation, organ culture and transplantation. Diabetes 22, 877-912 (1973)

14. Lillehei, R. C., Simmons, R. I.., Najarian, J. S., Weil, R., Uchida, H., Ruitz, J. O., Kjellstrand, C. M., Goetz, F. C.: Pancreatico-duodenal allotransplantation: Experimental and clinical experience. Acta diabet. lat. 7, 889-908 (1970) 
15. Matsuyama, T., Hoffman, W. H., Dunbar, J. C., Foà, N. L., Foà, P. P.: Glucose, insulin, pancreatic glucagon and glucagon-like immunoreactive materials in the plasma of normal and diabetic children. Effect of the initial insulin treatment. Horm. Metab. Res. 7, 452-456 (1975)

16. Natvig, H.: Hye høide - vekttabeller for norske kvinner og menn. Landsforeningen for kosthold og helse, Oslo 1956

17. Parving, H.-H., Noer, J., Deckert, T., Evrin, P. E., Nielsen, S. L., Lyngsøe, J., Rørth, M., Svendsen, P. Aa., Trap-Jensen, J., Lassen, N. A.: The effect of metabolic regulation on microvascular albumin permeability in short term diabetics. Diabetologia 11, 368 (1975)

18. Service, F. J., Molnar, G. D., Rosevear, J. W., Ackerman, E., Galewood, L. C., Taylor, W. F.: Mean amplitude of glycemic excursions, a measure of diabetic instability. Diabetes 19, 644-656 (1970)

19. Sherwin, R. S., Kramer, K. J., Tobin, J. D., Insel, P. A., Liljenquist, J. E., Berman, M., Andres, R.: A model of the kinetics of insulin in man. J. clin. Invest. 53, 1481-1492 (1974)

20. Slama, G., Hautecouverture, M., Assan, R., Tchobroutsky, G.:
One to five days of continous intravenous insulin infusion on seven diabetic patients. Diabetes 23, 732-739 (1974)

21. Sterky, G. C. G., Persson, B. E. H., Larsson, Y. A. A.: Dietary fats, the diurnal blood lipids and ketones in juvenile diabetes. Diabetologia 2, 14-19 (1966)

22. Unger, R. H., Orci, L.: The essential role of glucagon in the pathogenesis of diabetes mellitus. Lancet 1975 I, 14-16

23. Wide, C.: Radioimmunoassays employing immunosorbents. Acta endocr. (Kbh.) Suppl. 142, 207-218 (1969)

24. Østerby, R.: Early phases in the development of diabetic glomerulopathy. Acta med. scand. Suppl. 574, 52 (1974)

Received: March 1, 1976, and in revised form: July 26, 1976

Dr. T. Deckert

Niels Steensens Hospital

Niels Steensenvej 2

DK-2820 Gentofte

Denmark 